\title{
Decrease of Lipase and Esterase Activities in Intestinal Contents of Newborn Infants during Test Meals
}

\author{
BO FREDRIKZON ${ }^{(28)}$ AND THOMAS OLIVECRONA \\ Department of Paediatrics and Department of Chemistry, Section on Physiological Chemistry, University of \\ Umeå, Umeå, Sweden
}

\begin{abstract}
Summary
Both lipase and esterase activities were present in intestinal contents of all newborns studied, from the first day of life. In adults given a test meal lipase activity increased and esterase activity remained unchanged. In contrast, both activities decreased markedly in infants on feeding. During the digestion of the test meal the lipase activity in intestinal contents of the infants was much lower than in adults (ratio of median values $1: 27$ ) and the esterase activity was also several fold lower (ratio of median values $1: 4.3$ ).
\end{abstract}

\section{Speculation}

Newborn infants often absorb lipids less efficiently than adults. One contributing factor may be that their incompletely developed pancreas responds to feedings with comparatively low outputs of lipolytic enzymes. The newborn may be more dependent than adults on auxiliary sources of lipase activity such as the pharyngeal lipase and/or the bile salt-stimulated lipase in human milk.

Absorption of dietary lipids proceeds less efficiently in infants than in children and adults $(20,21,23)$. Deficient solubilization of lipids and of lipolytic products formed in the intestine because of low concentrations of intestinal bile salts has been suggested as an important factor limiting the utilization of lipids in infants $(17,20,22)$. Another possible explanation could be low intestinal activity of lipolytic enzymes. At birth the human exocrine pancreas seems not to be completely developed. After iv stimulation with intestinal hormones (secretin and cholecystokininpancreozymin) lower outputs of bicarbonate and enzymes from the pancreas were found in infants as compared to older subjects $(6,24)$. A response of adult level to such stimulation is not found until the child reaches the age of about 2 years (6). Furthermore, mature histologic structure of the gland does not appear until this age (19).

Dietary lipids, consisting mainly of long chain triglycerides, must be transformed into more polar products, e.g., fatty acids and monoglycerides, before they are absorbed by the intestinal mucosal cells. The lipolytic process begins already in the stomach where an appreciable amount of the dietary triglycerides are hydrolyzed to mainly diglycerides and fatty acids $(13,14,18)$ by a lipase which is probably secreted in the pharynx $(1,14)$. Further hydrolysis to primarily 2-monoglycerides and fatty acids then takes place in the intestine by the action of pancreatic lipase (EC 3.1.1.3). Together with intestinal bile salts these products form water-soluble aggregates, mixed micelles, which then carry the lipolytic products to the intestinal mucosa for absorption (16).

Pancreatic juice also contains a carboxylic ester hydrolase (EC 3.1.1.1) which will be called "esterase" in the following text.
This enzyme is usually assayed against water soluble esters. However, in the presence of bile salts it also hydrolyzes some lipids, e.g., monoglycerides, cholesteryl esters, retinol esters (8, $10)$ and may have a role in the digestion and absorption of these compounds. The activity of this enzyme has not previously been measured in infants. In the present study lipase and esterase activities were measured in duodenal contents collected from fasting newborns and adults and the activities were followed during a test meal.

\section{MATERIALS AND METHODS}

\section{INTESTINAL INTUBATION AND SAMPLING}

Ten fasting infants (clinical data are listed in Table 1) were investigated as follows: before a scheduled meal a feeding tube was introduced into the stomach and by gentle manipulation, sometimes with the aid of a guide wire, the tip of the tube was passed into the duodenum which was indicated by a flow of bile stained juice with $\mathrm{pH}$ above 5 as measured with $\mathrm{pH}$-indicator papers.

Duodenal contents were collected from seven other preterm infants (clinical data are listed in Table 2) before and at intervals after the intake of a test meal of heated human milk. Before the test meal was given the desired position of the feeding tube, i.e., near the ligament of Treitz, was in each case controlled by fluoroscopy. In order to control that the feeding tube remained in the duodenum throughout the sampling period the $\mathrm{pH}$ of each specimen was measured with a $\mathrm{pH}$ meter. In some infants duodenal contents were collected during two consecutive meals. At the time for this study, all infants were bottle fed pasteurized human milk or cow's milk formula every third or fourth hour and were thriving well on this regimen. Further, seven healthy adults were studied with the same technique (clinical data are listed in Table 2).

When possible about one $\mathrm{ml}$ of duodenal content was syphoned into ice-cooled tubes. To prevent proteolytic inactivation of the esterase activity $0.2-0.5 \mathrm{ml}$ of each sample was immediately diluted 1:5-1:20 with $0.5 \mathrm{M}$ Tris- $\mathrm{HCl}$ buffer, $\mathrm{pH}$ $7.4,6.0 \mathrm{mM}$ in sodium taurocholate (9). Thus diluted the esterase activity was stable for at least one week at $+4^{\circ}$. The remaining part of each sample was frozen and stored at $-20^{\circ}$ until lipase activities were measured.

\section{TEST MEALS}

The infants were given, at the time for a scheduled meal, heated human milk, $20-30 \mathrm{ml} / \mathrm{kg}$ body wt, i.e., the same amount of milk as in an ordinary feeding. The milk was heated to inactivate the bile salt-stimulated lipase (15). The fat content of the milk was assumed to be $4 \%$ (12) and thus in each meal a fat load of $0.8-1.2 \mathrm{~g}$ milk fat was given per $\mathrm{kg}$ body wt. The adults were given test meals containing commercial cow's milk $(3 \%$ 
milk fat) and cream (40\% milk fat) mixed in appropriate proportions to give a fat load of $1.0-1.2 \mathrm{~g}$ milk fat $/ \mathrm{kg}$ body wt. Of this mixture, $450-850 \mathrm{ml}$ were given as the test meal.

\section{ASSAY METHODS}

Lipase activity in duodenal contents was measured by continuous titration of butyric acid released from mechanically emulsified tributyrin at $\mathrm{pH} 8(2,10,13)$. Borgström and Hildebrand (2) recently reported that lipase and colipase activities in human intestinal contents are similar, and that both these proteins are secreted in parallel on stimulation of pancreatic secretion by a test meal. At pH 8 lipase activity against tributyrin showed little change on addition of extra colipase (2). Colipase activities were not measured in the present study. However, in several cases bile salts were added to the assay but this caused no large change in the rate of lipolysis indicating that the infant's intestinal contents contained sufficient amounts of colipase to prevent strong inhibition of the lipase activity by bile salts. The assay conditions used here are favorable for pancreatic lipase and it is likely that the activity recorded reflects primarily this lipase. However, a lipase of intestinal origin has recently been described in the rat (11). If this lipase is present also in humans it might contribute to the activities recorded. At $\mathrm{pH} 8$ the lipase present in gastric contents has negligible activity (13) and should not make any significant contribution to the activities recorded in the present study.

Esterase activity in duodenal contents was measured at $\mathrm{pH}$ 7.4 according to Erlanson (8), with the following modification of substrate preparation: $100 \mu \mathrm{mol} p$-nitrophenyl acetate were dissolved in $1.0 \mathrm{ml}$ acetone and then added with a submerged pipette to $99 \mathrm{ml}$ distilled water. The release of $p$-nitrophenol was followed spectrophotometrically as described (13) or on a Rotochem II parallel fast analyzer (AMINCO) at $405 \mathrm{~nm}$ for $135 \mathrm{sec}$ after the addition of enzyme. The mmolar extinction coefficient for $p$-nitrophenol at $\mathrm{pH} 7.4$ was 13.9.

The release of butyric acid and $p$-nitrophenol, respectively, was linear with time and enzyme concentration under the conditions used. Reproducibility of the assay systems was tested

Table 1. Clinical data and laboratory findings in fasting subjects

\begin{tabular}{|c|c|c|c|c|c|c|}
\hline \multirow[b]{2}{*}{ Cases } & \multirow{2}{*}{$\begin{array}{c}\text { Gesta- } \\
\text { tional } \\
\text { age, } \\
\text { weeks }\end{array}$} & \multirow{2}{*}{$\begin{array}{c}\text { Birth wt } \\
\mathrm{g}\end{array}$} & \multirow{2}{*}{$\begin{array}{l}\text { Age, } \\
\text { days }\end{array}$} & \multicolumn{2}{|c|}{$\begin{array}{l}\text { Enzyme activities, } \\
\mathrm{U} / \mathrm{ml}\end{array}$} & \multirow[b]{2}{*}{ Comments } \\
\hline & & & & Lipase & Esterase & \\
\hline LT $1^{1}$ & 38 & 2930 & 1 & 21 & 3.8 & Normal \\
\hline LT $2^{1}$ & 38 & 2860 & 1 & 131 & 14.8 & Normal \\
\hline KK & 42 & 2970 & 2 & 48 & 8.7 & $\begin{array}{l}\text { Mild postna- } \\
\text { tal asphyxia }\end{array}$ \\
\hline $\mathrm{JN}$ & 43 & 3710 & 5 & 503 & & Extrasystoles \\
\hline $\mathrm{NN}$ & 40 & 4740 & 10 & 722 & & $\begin{array}{l}\text { Congenital } \\
\text { dacryocysti- } \\
\text { tis }\end{array}$ \\
\hline WG & 42 & 2050 & 12 & 178 & 27.7 & 2 \\
\hline $\mathrm{BN} 1^{1}$ & 34 & 2370 & 16 & 262 & 18.6 & $\begin{array}{l}\text { Mild respira- } \\
\text { tory distress }\end{array}$ \\
\hline $\mathrm{BN} 2^{1}$ & 34 & 2240 & 17 & 175 & 22.6 & Normal \\
\hline $\mathrm{KN}$ & 31 & 2100 & 19 & 104 & 3.2 & Normal \\
\hline MM & 33 & 2050 & 25 & 129 & 6.7 & Normal \\
\hline
\end{tabular}

${ }^{1}$ Twins.

${ }^{2}$ Light for date according to Swedish standard curves for intrauterine growth (7). by measuring the enzyme activities in one sample 10 times during one day. The mean activity of this sample against tributyrin was $692 \mathrm{U} / \mathrm{ml}, \mathrm{SD}=32(4.6 \%)$, the mean activity against $p$-nitrophenyl acetate was $14.2 \mathrm{U} / \mathrm{ml}, \mathrm{SD}=0.64$ $(4.5 \%)$. One enzyme unit is defined as that amount of enzyme that releases $1 \mu \mathrm{mol}$ fatty acid or $1 \mu \mathrm{mol} p$-nitrophenol/min; U/ $\mathrm{ml}$ refers to enzyme activity in $1 \mathrm{ml}$ duodenal juice.

Statistical analysis was performed according to Wilcoxon's rank sum test.

\section{RESULTS}

\section{FASTING SUBJECTS}

Enzyme activities recorded in fasting subjects are listed in Table 1 together with clinical data on each case. In a few samples the volumes were too small to allow measurements of both lipase and esterase activities. With this reservation both activities were always present in the samples studied. There was a large variation between values recorded in different individuals which precluded a meaningful comparison of lipase or esterase activities between subjects of different ages.

\section{TEST MEALS}

All samples of duodenal contents were bile stained before milk was given. In infants most samples collected during the first and second hours after feeding were visibly diluted with milk, in contrast to samples obtained from adults which were bile stained throughout the collecting period and in which only traces of clotted milk were seen. During the third hour after feeding samples from infants again became more bile stained.

Before the test meals the median lipase activity in duodenal contents from the infants was less than half the median value recorded in adults whereas there was no large difference in the median esterase activities (Fig. 1, Table 2). However, as pointed out above, the individual variation was large both in infants and in adults. After the test meal was given both lipase and esterase activities decreased rapidly in all but one infant and low activities were found during the first and second hours after feeding in all infants. Thereafter, both enzyme activities increased towards values recorded before the feeding. The lipase and esterase activities changed in a similar fashion during the test meal in all cases studied. In all the infants studied during two test meals a decrease of the lipase activity was also observed during the second test meal (Fig. 2).

In contrast to the findings in the infants, but in good agreement with previous studies $(2,5)$, the lipase activity in intestinal contents increased in the adults after the test meal (Fig. 1). Thus, whereas the difference in median lipase activities between adults and infants was only about 2-fold (statistically not significant) before the test meal, the difference increased during the test meal to more than 10-fold (median 27 -fold during the first hour, $P<0.01)$. The median esterase activity did not change markedly during the test meal in the adults (Fig. 1). Before the meal there was no significant difference in esterase activity between infants and adults, but the decrease of this activity in the infants (Fig. 1) resulted in a significant difference compared to the adults during the meal (median 4.3-fold during the first hour, $P<0.05$ ).

\section{DISCUSSION}

Both lipase and esterase activities were present in all newborns studied, from the first day of life. The median value for

Table 2. Clinical data on subjects studied during test meals and laboratory findings in samples of duodenal juice collected before feeding

\begin{tabular}{cccccc}
\hline Cases & Gestational age, weeks & Birth wt, g & Age & Lipase activity, U/ml & Esterase activity, U/ml \\
\hline Infants $(n=7)$ & $31-37$ & $1700-2525$ & $16-38$ days & $149-586$ & $12.2-32.9$ \\
Adults $(n=7)$ & & & $22-36$ years & $84-1127$ & $3.9-29.5$ \\
\hline
\end{tabular}




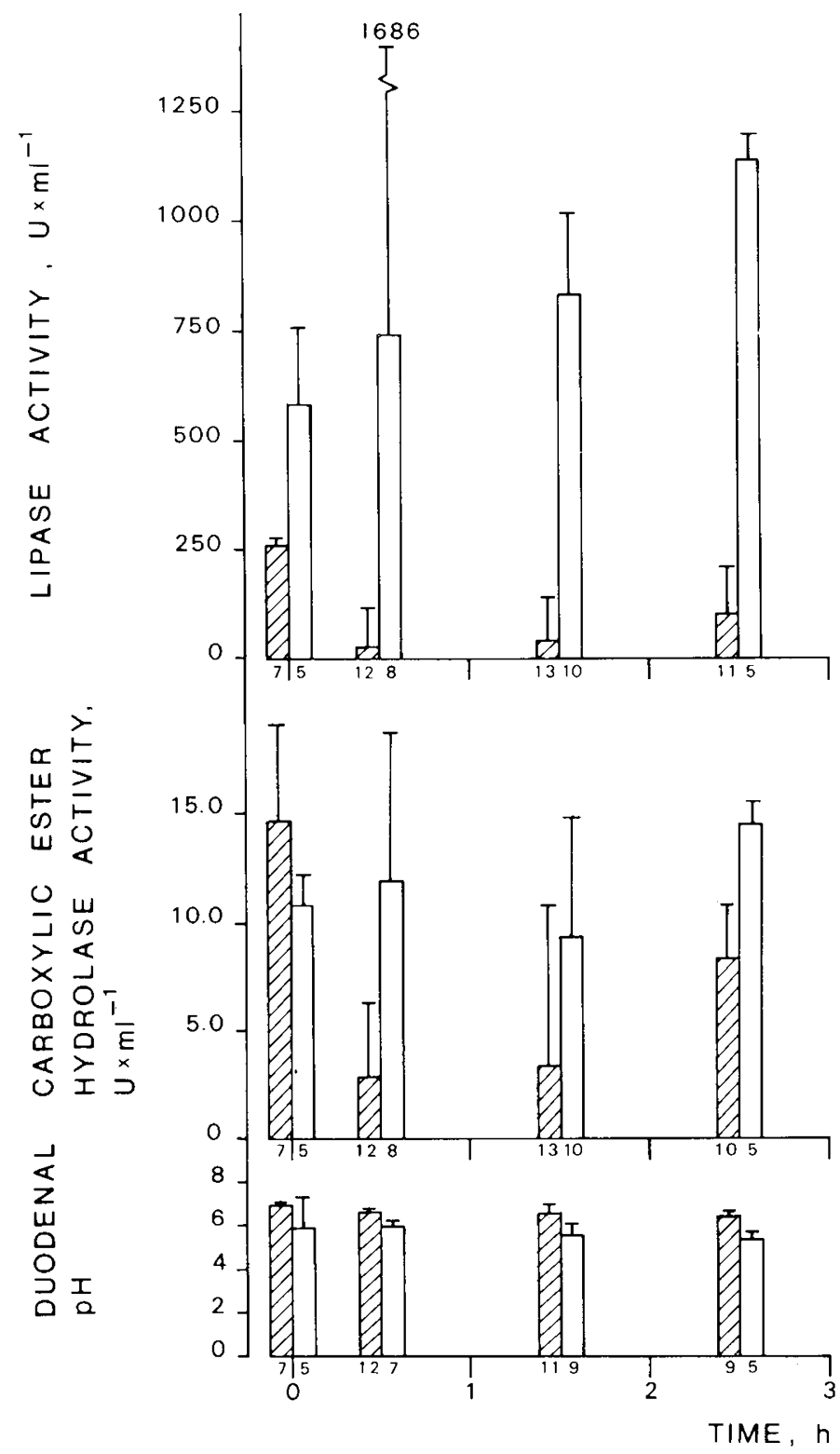

Fig. 1. Duodenal pH, carboxylic ester hydrolase, and lipase activities in infants (striped bar) and adults (open bar). Values obtained before feedings were pooled as were values obtained during the first, second, and third hour, respectively. The number of observations made during each time interval are given below each column. The columns represent the second quartile; the third quartile is indicated by $\tau$.

lipase activity was less in the infants than in the adults, but individual variations were large. However, to evaluate the digestive capacity, it is of much more interest to compare the enzyme activities during a test meal than under fasting conditions. In adults, the present study showed, in concert with previous observations, an increase of lipase activity upon feeding $(2,5)$. This is due to stimulation of pancreatic secretion by food (5). The response to feeding in the infants was strikingly different from that in adults. In all infants studied both lipase and esterase activities decreased several fold. Low activities of pancreatic enzymes after feeding have previously been reported in preterms by Borgström (3), in fullterm infants by Norman (17), and in healthy children (4). However, the actual decrease of enzyme activities as a result of feeding was not emphasized in these studies and no comparisons with the adult response to feeding were made. The present study demonstrates that although in adults the level of lipase activity is lower during fasting than during meals, in infants the level is much higher during

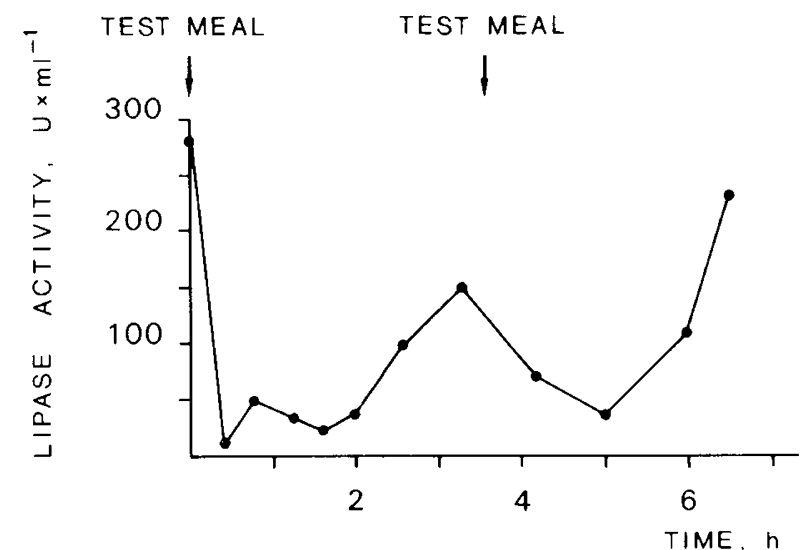

Fig. 2. Duodenal lipase activity during two consecutive feedings in a preterm infant.

fasting than during meals. It is possible that frequent feedings in infants result in a more or less constant flow of milk into the duodenum which creates a constant stimulus for the pancreas to secrete enzymes. Thus, the ability to further increase this secretion after a test meal may be small under the conditions we used. This is illustrated in Figure 2 where two consecutive test meals were given at times coinciding with the normal feeding routine for newborns. A further factor which certainly contributes to the low enzyme activities is the extensive dilution of the intestinal contents as a result of ingestion of comparatively large amounts of milk and rapid gastric emptying (17).

During the actual digestion of the test meal the lipase activities in the intestinal contents of the infants were much lower than in the adults (Fig. 1), and the esterase activities were also several fold lower. This may well result in a comparatively low rate of lipolysis which may impede the digestion and absorption of the milk lipids. This could contribute to the less efficient lipid absorption often observed in newborns.

\section{REFERENCES AND NOTES}

1. Bläckberg, L., Hernell, O., Fredrikzon, B., and Akerblom, H. K.: On the source of lipase activity in gastric contents. Acta Paediat. Scand., 66: 473 (1977).

2. Borgström, B., and Hildebrand, H.: Lipase and co-lipase activities of human small intestinal contents after a liquid test meal. Scand. J. Gastroenterol., 10: 585 (1975).

3. Borgström, B., Lindquist, B., and Lund, G.: Enzyme concentration and absorption of protein and glucose in duodenum of premature infants. Amer. J. Dis. Child., 99: 338 (1960)

4. Borgström, B., Lindquist, B., and Lund, G.: Digestive studies in children. Amer. J. Dis. Child. 101: 45 (1961).

5. Brunner, H., Northfield, T. C., Hofmann, A. F., Go, V. L. W., and Summerskill, W. H. J.: Gastric emptying and secretion of bile acids, cholesterol, and pancreatic enzymes during digestion. Mayo Clin. Proc., 49: 851 (1974).

6. Delachaume-Salem, E., and Sarles, H.: Evolution en fonction de l'age de la secretion pancreatique humaine normale. Biol. Gastroenterol., 2: 135 (1970).

7. Engström, L., Karlberg, P., Olsson, T., and Selstam, U.: Birth weight and height of newborn swedish infants with relation to gestational age. (In preparation.)

8. Erlanson, C.: p-Nitrophenyl acetate as a substrate for a carboxylester hydrolase in pancreatic juice and intestinal content. Scand. J. Gastroenterol., 5: $333(1970)$.

9. Erlanson, C.: Purification, properties and substrate specificity of a carboxylesterase in pancreatic juice. Scand. J. Gastroenterol., 10: 401 (1975).

10. Erlanson, C., and Borgström, B.: Tributyrine as a substrate for determination of lipase activity of pancreatic juice and small intestinal content. Scand. J. Gastroenterol., 5: 293 (1970).

11. Fernandez-Lopez, V., Serrero, G., Négrel, R., and Ailhaud, G.: Esterolytic activities of rat intestinal mucosa. II. Purification and properties of a glycerol-ester hydrolase. Eur. J. Biochem., 71: 259 (1976).

12. Fomon, S. J., and Filer, L. J., Jr.: Milks and formulas. In: S. J. Fomon: Infant Nutrition, Ed. 2, p. 359 (W. B. Saunders, Philadelphia, 1974).

13. Fredrikzon, B., and Hernell, O.: Role of feeding on lipase activity in gastric contents. Acta Paediat. Scand., 66: 479 (1977).

14. Hamosh, M., Klaeveman, H. L., Wolf, R. O., and Scow, R. O.: Pharyngeal lipase and digestion of dietary triglyceride in man. J. Clin. Invest. 55: 908 (1975).

15. Hernell, O.: Human milk lipases. III. Physiological implications of the bile 
salt-stimulated lipase. Eur. J. Clin. Invest., 5: 267 (1975).

16. Johnston, J. M.: Mechanism of fat absorption. In: C. F. Code and W. Heidel: Handbook of Physiology, Section 6, Vol. III, p. 1353 (The Williams \& Wilkins Co., Baltimore, 1967).

17. Norman, A., Strandvik, B., and Ojamäe, Ö.: Bile acids and pancreatic enzymes during absorption in the newborn. Acta Paediat. Scand., 61: 571 (1972).

18. Olivecrona, T., Billström, Å., Fredrikzon, B., Johnson, O., and Samuelson, G.: Gastric lipolysis of human milk lipids in infants with pyloric stenosis. Acta Paediat. Scand., 62: 520 (1973).

19. Seifert, G.: Die Pathologie des kindlichen Pancreas, p. 11 (VEB Georg Thieme, Leipzig, 1956).

20. Signer, E., Murphy, G. M., Edkins, S., and Anderson, C. M.: Role of bile salts in fat malabsorption of premature infants. Arch. Dis. Childhood, 49: 174 (1974).

21. Watkins, J. B., Bliss, C. M., Donaldson, R. M., Jr., and Lester, R.: Characterization of newborn fecal lipid. Pediatrics, 53: 511 (1974)

22. Watkins, J. B., Szczepanik, P., Gould, J. B., Klein, P., and Lester, R.: Bile salt metabolism in the human premature infant. Gastroenterology, 69: 706 (1975).

23. Weijers, H. A., Drion, E. F., and van de Kamer, J. H.: Analysis and interpretation of the fat-absorption coefficient. Acta Paediat. Scand, 49: $615(1960)$.

24. Zoppi, G., Andreotti, G., Pajno-Ferrara, F., Njai, D. M., and Gaburro, D.: Exocrine pancreas function in premature and fullterm neonates. Pediat. Res., 6: 880 (1972).

25. This study was approved by the Committee on Research Involving Human Subjects of the Medical Faculty, University of Umeå.

26. Informed consent was obtained from the parents of each infant

27. This research was supported by grants from the Swedish Nutrition Foundation, Semper Fund for Nutritional Research, AB Findus and the Medical Faculty, University of Umeå.

28. Requests for reprints should be addressed to: Bo Fredrikzon, M.D., Department of Paediatrics, University of Umeå, S-901 85 Umeå (Sweden).

29. Received for publication May 31,1977

30. Accepted for publication August 24, 1977.

0031-3998/78/1205-0631\$02.00/0

Copyright (c) 1978 International Pediatric Research Foundation, Inc

Printed in U.S.A. 